\title{
Analytic Hierarchy Process (AHP) Methods For Evaluation of Teacher Quality
}

\author{
Julyeta P.A. Runtuwene ${ }^{1}$ \\ Department of Informatics \\ Universitas Negeri Manado \\ Manado, Indonesia \\ 1julyeta.par@unima.ac.id
}

\author{
Irene R.H.T. Tangkawarow ${ }^{2}$, Mario T. Parinsi ${ }^{3}$ \\ Department of Education in Information Technology and \\ Communication \\ Universitas Negeri Manado \\ Manado, Indonesia \\ 2irene.tangkawarow@unima.ac.id, \\ ${ }^{3}$ marioparinsi@unima.ac.id
}

\begin{abstract}
Generally, if there are several complex criteria, constraints will occur in decision making. The decision making process faces the priority of several alternatives. Sometimes, decision making occurs using mere subjective values. This is not supposed to happen in determining teacher's quality. Based on Indonesian Law No. 14 of 2005 concerning Teachers and Lecturers, it is stated that the intended teacher competencies are pedagogic competence, personality competence, social competence, and professional competence. These four criteria are the basic criteria for determining teacher's quality. The Analytic Hierarchy Process (AHP) method is one of the methods in the Multi Criteria Decision Method (MCDM) which can provide solutions to support decision makers to determine the quality of teachers to be assessed. The results of this study are in the form of an application to determine the quality of teachers based on the ratings assessed from the four criteria with 19 sub criteria. Based on the experimental results, the criteria used for consistency of weighted priority level analysis were found to be consistent and the best quality of teacher based on all available alternatives. So the results of alternative rankings can be used as basic guidelines to help decision making.
\end{abstract}

Keywords-Decision support, teacher competencies, MCDM, AHP, teacher quality.

\section{INTRODUCTION}

Teachers become one of determiners of Education Quality. In Act No.14 year 2005 about teachers and lecturers and the Regulation of State Minister for Utilization of State Apparatus and Bureaucracy Reformation No. 16 year 2009 about teacher's functional position and its credit number, teachers have to perform 4 competences namely: pedagogic, personality, social and professional competence and a professional teacher has to conduct Continuing Professionality Development (CPD). CPD means selfdevelopment, scientific publication and innovative works.

This study is meant to overcome problems in decision making related to the continuing of teacher's quality. The background of problem in this study is based on the national issue nowadays that professional teachers have orientation not on the quality of their profession but only on remuneration, instead; there is a difficulty to analyze data to assist decision making process of professional teacher's quality/; there is also a difficulty to make a data report either in the aspect of quality, accuracy or time, therefore it is hard to determine reward and punishment for professional teachers. Reference [1] in his research, divides categories of continuing development assessment for professionality of certified teachers with the following categories: high, average and low. A conducted research for teachers of SMK Technology in the entire Malang Raya, there is lack of interest for the certified teachers to upgrade or improve their competence of professionalism. Reference [2] in his research states that Indonesian Government effort will be useless when the performance of certified teachers (professional teachers) is not better than that before being certified. This happens when after being certified their performance decline because they no longer feel being assessed and given no sanction. This is the reason why evaluation needs to be done for certified teachers sustainably.

Criteria that will be used in this study are taken from [3] research in which certified teachers have to fulfill several criteria that can be seen from table I as follows:

TABLE I. CRITERIA AND SUB CRITERIA OF PROFESSIONAL TEACHERS

\begin{tabular}{|l|l|l|l|}
\hline No & \multicolumn{1}{|c|}{ Criteria } & \multicolumn{1}{c|}{ Sub Criteria } & \multicolumn{1}{c|}{ Explanation } \\
\hline 1. & $\begin{array}{l}\text { Pedagogic } \\
(\text { Pe) }\end{array}$ & $\begin{array}{l}\text { Understanding learners } \\
\text { (Pe1) } \\
\text { Designing RPP (Pe2) } \\
\text { Performing RPP (Pe3) } \\
\text { Evaluating learning } \\
\text { outcome (Pe4) } \\
\text { Developing learners } \\
\text { (Pe5) }\end{array}$ & $\begin{array}{l}\text { Reflected from the level } \\
\text { of understanding of } \\
\text { students, design and } \\
\text { execution of learning, } \\
\text { evaluation of learning } \\
\text { outcome and } \\
\text { development of } \\
\text { students to actualize the } \\
\text { various potentials } \\
\text { owned }\end{array}$ \\
\hline 2. & $\begin{array}{l}\text { Personality } \\
(\text { K) }\end{array}$ & $\begin{array}{l}\text { Steady personality, } \\
\text { stable, mature, skillful, } \\
\text { authoritative (K1) } \\
\text { Become an example for } \\
\text { his learners (K2) } \\
\text { Become an example for } \\
\text { the people (K3) } \\
\text { Has noble personality } \\
\text { (K4) }\end{array}$ & $\begin{array}{l}\text { Reflected from personal } \\
\text { personality, stable, } \\
\text { mature, skillful, } \\
\text { authoritative, become } \\
\text { an example for his } \\
\text { learners and people and } \\
\text { has noble personality. }\end{array}$ \\
\hline 3. & Social (S) & $\begin{array}{l}\text { Able to communicate } \\
\text { and associate }\end{array}$ & $\begin{array}{l}\text { Reflected from } \\
\text { teacher's ability to }\end{array}$ \\
\hline
\end{tabular}




\begin{tabular}{|c|c|c|c|}
\hline No & Criteria & Sub Criteria & Explanation \\
\hline & & $\begin{array}{l}\text { effectively with } \\
\text { learners (S1) } \\
\text { Able to communicate } \\
\text { and associate } \\
\text { effectively with the } \\
\text { same teachers (S2) } \\
\text { Able to communicate } \\
\text { and associate } \\
\text { effectively with } \\
\text { parents/guardians of } \\
\text { learners (S3) } \\
\text { Able to communicate } \\
\text { and associate } \\
\text { effectively with } \\
\text { surrounding people } \\
\text { (S4) }\end{array}$ & $\begin{array}{l}\text { communicate and } \\
\text { mingle with learners, } \\
\text { teachers, educators, } \\
\text { parents/guardians and } \\
\text { people effectively }\end{array}$ \\
\hline 4. & $\begin{array}{l}\text { Professional } \\
\text { (Pr) }\end{array}$ & $\begin{array}{l}\text { Mastering the learning } \\
\text { material broadly (Pr1) } \\
\text { Mastering the } \\
\text { curriculum material and } \\
\text { knowledge substance } \\
\text { comprising the material } \\
\text { (Pr2) } \\
\text { Mastering the structure } \\
\text { and methodology of his } \\
\text { knowledge (Pr3) }\end{array}$ & $\begin{array}{l}\text { Reflected from the } \\
\text { mastery of learning } \\
\text { material broadly and } \\
\text { deeply covering } \\
\text { curriculum of subject } \\
\text { materials at school and } \\
\text { the substance of } \\
\text { knowledge comprising } \\
\text { the material and the } \\
\text { mastery of structure and } \\
\text { methodology of his } \\
\text { knowledge. }\end{array}$ \\
\hline 5 . & $\begin{array}{l}\text { Innovation } \\
\text { development } \\
\text { (Pi) }\end{array}$ & $\begin{array}{l}\text { Availability of } \\
\text { scientific publication } \\
\text { (Pi1) } \\
\text { Created innovative } \\
\text { works (Pi2) }\end{array}$ & $\begin{array}{l}\text { Reflected from the } \\
\text { ability in } \\
\text { innovation/developing } \\
\text { innovation of teacher's } \\
\text { knowledge applied in } \\
\text { teaching and learning } \\
\text { activity. }\end{array}$ \\
\hline 6. & $\begin{array}{l}\text { Utility of } \\
\text { technology } \\
\text { (Pt) }\end{array}$ & $\begin{array}{l}\text { Utility of information } \\
\text { technology in teaching } \\
\text { and learning activity } \\
\text { (Pt1) }\end{array}$ & $\begin{array}{l}\text { Reflected from the } \\
\text { ability to use/apply } \\
\text { technology in teaching } \\
\text { and learning activity. }\end{array}$ \\
\hline
\end{tabular}

\section{PROPOSED METHOD}

\section{A. Multi Criteria Decision Making (MCDM)}

MCDM method is developed to support decision making process [4][5]. MCDM is used a lot as a tool to solve problems for performance-type, resource management, policy and strategy of a company, public policy, political strategy and planning [4-12]. Decision supporter plays a role to give support in decision making and not replacing the role of decision maker. In other words, decision supporter exists to improve efficiency in decision making [9].

\section{B. Analytic Hierarchy Process (AHP)}

One of methods in MCDM is Analytic Hierarchy Process (AHP). This method is developed by Thomas. L Saaty, an expert mathematician who worked at University of Pittsburg America in early 1970 's. It is a framework to make a decision effectively to complex problems to simplify and accelerate decision making process by solving problems into a smaller part, to arrange this part or variable in one hierarchy, to give numerical value to subjective consideration about the importance of each variable and synthesize this various consideration to determine which variable having the highest priority and acting to influence the result in that situation[13].
It is particularly useful method when the decision maker is unable to construct utility function [6]. In Fig. 1 shows the AHP Hierarchical structure 3 levels.

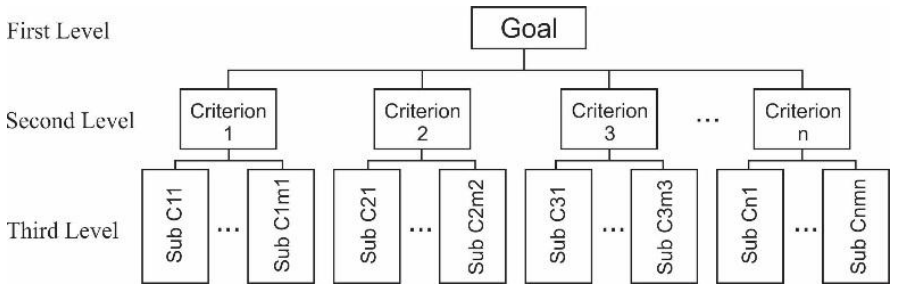

Fig. 1. Hierarchical structure of the AHP

Based on [12] in [9] there are 10 steps in Analytical Hierarchy Process (AHP) are as follows:

1. The first step we need determine the problem then set the solution and compile the problem encountered hierarchy;

2. Comparing each criterion in pairs to define the criteria weight. This process uses the Pair-wise Comparison Judgement Matrices (PCJM) method based on priority scheme, described in Table II:

TABLE II. RATIO SCALE IN THE AHP [14], [9].

\begin{tabular}{|c|l|l|}
\hline $\begin{array}{c}\text { Intensity } \\
\text { of } \\
\text { Interest }\end{array}$ & Linguistic & \multicolumn{1}{|c|}{ Information } \\
\hline 1 & Equal & $\begin{array}{l}\text { Both elements are same } \\
\text { important }\end{array}$ \\
\hline 3 & Moderate & $\begin{array}{l}\text { One element is not considerably } \\
\text { more important than the other }\end{array}$ \\
\hline 5 & Strong & $\begin{array}{l}\text { One element is more important } \\
\text { than the other }\end{array}$ \\
\hline 7 & Demonstrated & $\begin{array}{l}\text { One element is obviously more } \\
\text { important than any other element }\end{array}$ \\
\hline 9 & Extreme & $\begin{array}{l}\text { One of the most extremely } \\
\text { important elements of the other } \\
\text { elements }\end{array}$ \\
\hline $2,4,6,8$ & $\begin{array}{l}\text { Intermediate } \\
\text { Value }\end{array}$ & $\begin{array}{l}\text { Values between two adjacent } \\
\text { consideration values }\end{array}$ \\
\hline Inverse & $\begin{array}{l}\text { If for activity “i” gets one number over activity “j”, } \\
\text { then “j” has its opposite value than "i”" }\end{array}$ \\
\hline
\end{tabular}

3. Summing the value of each matched pair matrix column then dividing each value from the column with the sum of the corresponding columns. This step will perform normalization on a pairwise comparison matrix.

$$
\bar{a}_{j k}=\frac{\bar{a}_{j k}}{\sum_{l=1}^{m} a_{l k}}
$$

4. Calculates the synthesis weight by sum every column in the similar row from the comparison normalization result of the matrix.

$$
\sum \text { column }=k_{1}+k_{2}+k_{3}+\cdots+k_{n}
$$

5. Calculates the eigenvalues by multiply each matched matrix columns in the similar row, then being lifted by an existing criterion number.

$$
\lambda_{1}=\left(k_{1} \times k_{2} \times k_{3} \times \ldots k_{n}\right)^{1 / n}
$$


6. Calculates each criterion priority weight by means of the eigenvalues for each criterion divided by the total number of eigenvalues.

7. Divide the synthesis weight by priority weight to calculates the importance of each criterion.

8. Divide the total number of importance values by the number of criteria to calculate the maximum eigenvalue $\left(\mu_{\max }\right)$.

9. Measures the consistency of use to ensure that judgment for decision making is high consistency.

$$
C I=\frac{\left(\mu_{\max }-n\right)}{n-1}
$$

Where,

$$
\begin{array}{ll}
C I & =\text { Consistency Index } \\
\mu_{\max } & =\text { Maximum eigenvalue } \\
n & =\text { Number of elements }
\end{array}
$$

10. Based on Saaty [15] suggested that $C R$ value should not exceed 0.1 for a confident result. Calculate $C R$ by divided consistency index and index random consistency.

$$
C R=\frac{C I}{R I}
$$

Where: IR

$C R=$ Consistency Ratio

$C I=$ Consistency Index

$R I=$ Index Random Consistency

$R I$ values can be seen in Table below

TABLE III. THE R.I For DifFERENCE Size MATRICES [15]

\begin{tabular}{|c|c|}
\hline $\begin{array}{c}\text { Number of } \\
\text { elements }\end{array}$ & R.I \\
\hline $\mathbf{3}$ & 0.52 \\
\hline $\mathbf{4}$ & 0.89 \\
\hline $\mathbf{5}$ & 1.11 \\
\hline $\mathbf{6}$ & 1.25 \\
\hline $\mathbf{7}$ & 1.35 \\
\hline $\mathbf{8}$ & 1.40 \\
\hline $\mathbf{9}$ & 1.45 \\
\hline $\mathbf{1 0}$ & 1.49 \\
\hline $\mathbf{1 1}$ & 1.51 \\
\hline $\mathbf{1 2}$ & 1.54 \\
\hline $\mathbf{1 3}$ & 1.56 \\
\hline
\end{tabular}

Accuracy Testing is closeness measurement of measurement result to the true value/ reference value. In this research, this accuracy testing is conducted to see the capacity of this calculation in decision making. In the research of [9] accuracy calculation is done by calculating the number of accurate diagnosis divided by total data. This level of accuracy can be obtained by using the following calculation:

$$
\text { accuracy }=\frac{\sum \text { true test data }}{\sum \text { test data }} \times 100 \%
$$

\section{MAIN RESULT}

In this research, we did several steps shown in below. The first step we determine data sets which we collected from Department of Education and Culture in Manado City and the next step is based from the AHP steps below. Fig. 2 shows the flow diagram of AHP work process.

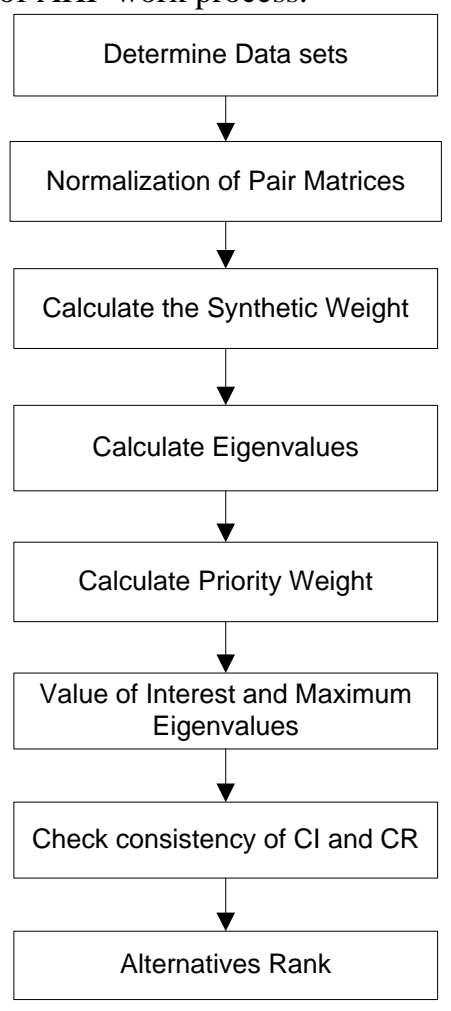

Fig. 2. Research Flow Chart

In the early step after teachers' assessment data were obtained, the researcher made comparison matrices by using Pair-wise Comparison Judgment Matrices Method (PCJM). The matrix of comparison result was done on each criterion, one of matrices for Pedagogic Criteria can be seen on Table IV as follows:

TABLE IV. PEDAGOGIC CRITERIA PAIR-WISE COMPARISON MATRICES

\begin{tabular}{|c|c|c|c|c|c|}
\hline Pedagogic (Pe) & Pe1 & Pe2 & Pe3 & Pe4 & Pe5 \\
\hline PE1 & 1.00 & 3.00 & 3.00 & 5.00 & 2.00 \\
\hline PE2 & 0.33 & 1.00 & 3.00 & 3.00 & 0.33 \\
\hline PE3 & 0.33 & 0.33 & 1.00 & 3.00 & 0.33 \\
\hline PE4 & 0.20 & 0.33 & 0.33 & 1.00 & 0.25 \\
\hline PE5 & 0.50 & 3.00 & 3.00 & 4.00 & 1.00 \\
\hline
\end{tabular}

The next step is to analyze criteria by conducting normalization to all pair-wise matrices in all criteria by using the formula on equation (1) above. Then priority vector calculation was done by using equation (2) and equation (3) for the result of normalization which was obtained from pairwise matrices and priority vector for pedagogic criteria, can be seen on the following table: 
TABLE V. Normalization AND Priority Vector of PEDAgogic CRITERIA

\begin{tabular}{|c|c|c|c|c|c|c|c|}
\hline $\begin{array}{c}\text { Normalization } \\
(\text { Pe })\end{array}$ & Pe1 & Pe2 & Pe3 & Pe4 & Pe5 & SUM & $\begin{array}{c}\text { Priority } \\
\text { vector }\end{array}$ \\
\hline PE1 & 0.42 & 0.39 & 0.29 & 0.31 & 0.51 & 1.93 & 0.39 \\
\hline PE2 & 0.14 & 0.13 & 0.29 & 0.19 & 0.09 & 0.83 & 0.17 \\
\hline PE3 & 0.14 & 0.04 & 0.10 & 0.19 & 0.09 & 0.55 & 0.11 \\
\hline PE4 & 0.08 & 0.04 & 0.03 & 0.06 & 0.06 & 0.29 & 0.06 \\
\hline PE5 & 0.21 & 0.39 & 0.29 & 0.25 & 0.26 & 1.40 & 0.28 \\
\hline
\end{tabular}

Before doing the ranking, it is important to conduct consistency testing from the result of priority vector calculation, in which the value of $C R$ from all calculation in each criterion must be evidenced. The true value is determined by the value of $C R<0,1$ [15].

\begin{tabular}{|c|c|c|c|c|c|}
\hline Criteria & $\boldsymbol{\mu}_{\text {max }}$ & CI & RI & CR & Result \\
\hline Pedagogic (Pe) & 5.28569 & .0714 & 1.11 & 0.0643 & $\begin{array}{c}\text { Consistent } \\
(\mathrm{CR}<0.1)\end{array}$ \\
\hline $\begin{array}{c}\text { Personality } \\
(\mathrm{K})\end{array}$ & 4.07159 & 0.0239 & 0.89 & 0.0268 & $\begin{array}{c}\text { Consistent } \\
(\mathrm{CR}<0.1)\end{array}$ \\
\hline Social (S) & 4.01454 & 0.0048 & 0.89 & 0.0054 & $\begin{array}{c}\text { Consistent } \\
(\mathrm{CR}<0.1)\end{array}$ \\
\hline Professional (Pr) & 3.00921 & 0.0046 & 0.52 & 0.0089 & $\begin{array}{c}\text { Consistent } \\
(\mathrm{CR}<0.1)\end{array}$ \\
\hline $\begin{array}{c}\text { Innovation } \\
\text { development (Pi) }\end{array}$ & 2.00000 & 0 & 0 & 0 & $\begin{array}{c}\text { Consistent } \\
(\mathrm{CR}<0.1)\end{array}$ \\
\hline $\begin{array}{c}\text { Utility of } \\
\text { technology (Pt) }\end{array}$ & 1.00000 & 0 & 0 & 0 & $\begin{array}{c}\text { Consistent } \\
(\mathrm{CR}<0.1)\end{array}$ \\
\hline
\end{tabular}

From the table above, there are 2 criteria in which the consistency testing is not necessary to be calculated because the $R I$ value is nil with each of number of elements $n$ is 2 and 1. In the last step, assessment of final weight on each criterion was done and continued with ranking by using the data of teachers' assessment result. Table A1 in Appendix shows the result using priority vector of each sub indicator. From the calculation above, the last result of assessment for 3 highest values are shown in the following Table A2 in Appendix.

The testing of accuracy level where in this case the level of conformity obtained by expert which will be searched with data calculated by using AHP method is as follows:

$$
\text { accuracy }=\frac{26}{30} \times 100 \%=86.67 \%
$$

It is obtained that the accuracy level is $86.67 \%$ resulted from true data test which is 26 and the number of data test is 30 .

\section{CONCLUSION}

This research determines and evaluate the teacher's quality in doing their duties and responsibilities as educators uses 6 criteria with 19 sub-criteria. The level of priority for each criterion shows that pedagogic criteria is an understanding to learners/students (Pe1) with priority vector of 0.39 ; personality criteria is to have a noble character (K4) with priority vector 0.482 ; professional criteria is to master broadly learning material (Pr1) with priority vector of 0.54 ; innovative development criteria is the availability of scientific publication (Pi1) with priority vector of 0.75 and the last is the utility of information technology. From 30 teacher assessment alternatives by using AHP, the 3 highest final results are obtained namely:7.334, the second is 7.302 and the third is 7.277. The accuracy level using AHP in this case is $86.67 \%$.

\section{ACKNOWLEDGMENT}

The authors express their sincere thanks and appreciations to Lembaga Penelitian dan Pengabdian kepada Masyarakat (LPPM) Universitas Negeri Manado for their valuable contributions and supports on this research.

\section{REFERENCES}

[1] Sujianto, "Pengembangan Profesionalitas Berkelanjutan/Continuing Proffesionality Development (CPD) Guru Bersertifikat Pendidik di SMK Rumpun Teknologi se-Malang Raya,” J. Pendidik. Sains, vol. 1, no. 2, pp. 159-170, 2013.

[2] A. Jaedun, "Pengembangan Keprofesionalan Guru Secara Berkelanjutan," [Online]. Available: http://staffnew.uny.ac.id/upload/ 131569339/pengabdian/pengembangan-keprofesionalanberkelanjutan.pdf. [Accessed: 30-Aug-2018].

[3] D.R. Bahari, E. Santoso, and S. Adinugroho, "Sistem Pendukung Keputusan Penentuan Guru Berprestasi Menggunakan Fuzzy-Analytic Hierarchy Process (F-AHP) (Studi Kasus: SMA Brawijaya Smart School)," J. Pengemb. Teknol. Inf. dan Ilmu Komput., vol. 2, no. 5, pp. 2095-2101, 2018.

[4] U. Yudatama and R. Sarno, "Evaluation Maturity Index and Risk Management for IT Governance Using Fuzzy AHP and Fuzzy Topsis," Int. Semin. Intell. Technol. Its Appl., pp. 323-328, 2015.

[5] M. Velasquez and P.T. Hester, "An Analysis of Multi-Criteria Decision Making Methods,” Int. J. Oper. Res., vol. 10, no. 2, pp. 56-66, 2013.

[6] A. Ishizaka and P. Nemery, Multi-Criteria Decision Analysis. 2013.

[7] A. Ozdagoglu and G. Ozdagoglu, "Comparison of Ahp and Fuzzy Ahp for the Multi- Criteria Decision Making Processes With Linguistic Evaluations," İstanbul Ticaret Üniversitesi Fen Bilim. Derg., vol. 6, no. 1, pp. 65-85, 2007.

[8] D.Y. Chang, "Applications of the extent analysis method on fuzzy AHP,” Eur. J. Oper. Res., vol. 95, no. 3, pp. 649-655, 1996.

[9] A. Cahyapratama and R. Sarno, "Application of Analytic Hierarchy Process (AHP) and Simple Additive Weighting (SAW) methods in singer selection process," 2018 International Conference on Information and Communications Technology (ICOIACT) Yogyakarta, pp. 234-239, 2018.

[10] R. Morgan, "An investigation of constraints upon fisheries diversification using the Analytic Hierarchy Process (AHP)," Mar. Policy, vol. 86, pp. 24-30, 2017.

[11] M. Celik, I. Deha, and A. F. Ozok, "Application of fuzzy extended AHP methodology on shipping registry selection: The case of Turkish maritime industry," Expert Syst. Appl., vol. 36, no. 1, pp. 190-198, 2009.

[12] Q. Xu and M. Xiong, "A Practical Method for Improving Consistency of Judgement Matrix in the Ahp," J. Syst. Sci. Complex., vol. 17, no. 2, pp. 169-175, 2004.

[13] A. Susanti, "Sistem Pendukung Keputusan Pemilihan Guru Berprestasi Menggunakan Metode Analytical Hierarchy Process Pada Smk Negeri 9 Semarang," unpublished.

[14] Morgan R, "An investigation of constraints upon fisheries diversification using the Analytic Hierarchy Process (AHP)," Mar. Policy, vol. 86, pp. 24-30, May 2017.

[15] T. Gwo-Hshiung and H. Jih.-Jeng, Multiple Attribute Decision Making: Method and Application. Boca Raton, Florida: CRC Press, 2011. 
APPENDIX

TABLE A1. NUMBER OF WEIGHT OF EACH ASSESSMENT AND RANKING

\begin{tabular}{|c|c|c|c|c|c|c|c|c|c|c|c|c|c|c|c|c|c|c|c|c|c|c|c|c|c|c|c|c|c|c|}
\hline \multirow{3}{*}{ Name } & \multirow{3}{*}{\begin{tabular}{|c|} 
Criteria \\
Priority \\
Vector
\end{tabular}} & \multicolumn{6}{|c|}{ Pedagogic (Pe) } & \multicolumn{5}{|c|}{ Personality (K) } & \multicolumn{5}{|c|}{ Social (S) } & \multicolumn{4}{|c|}{ Professional (Pr) } & \multicolumn{3}{|c|}{ Innovation $(P i)$} & \multicolumn{2}{|c|}{$\begin{array}{c}\text { Utility of } \\
\text { Tech }\end{array}$} & \multirow{3}{*}{$\begin{array}{c}\text { Number } \\
\text { of } \\
\text { values }\end{array}$} & \multirow{3}{*}{$\begin{array}{c}\text { Number } \\
\text { of } \\
\text { weights }\end{array}$} & \multirow{3}{*}{$\begin{array}{l}\text { Final } \\
\text { Result }\end{array}$} & \multirow[b]{3}{*}{ Ranl } \\
\hline & & Pe1 & $P e 2$ & $P e 3$ & Pe4 & $P e 5$ & \multirow[b]{2}{*}{$\begin{array}{l}\text { weight } \\
\text { of } P E\end{array}$} & $K 1$ & $K 2$ & $K 3$ & K4 & & $S 1$ & $S 2$ & $S 3$ & 54 & & Pr1 & Pr2 & Pr3 & & Pil & $P i 2$ & & $P t$ & & & & & \\
\hline & & के & $\stackrel{2}{8}$ & $\overline{7}$ & $\stackrel{8}{8}$ & $\stackrel{\text { ஸे }}{s}$ & & ปั้ & $\stackrel{1}{5}$ & $\stackrel{\Im}{\Im}$ & $\stackrel{a}{\frac{a}{8}}$ & $\begin{array}{c}\text { weight } \\
\text { of } K\end{array}$ & 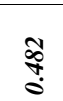 & 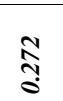 & $\frac{\infty}{2}$ & $\stackrel{\infty}{\stackrel{0}{0}}$ & $\begin{array}{c}\text { Weight } \\
\text { of } S\end{array}$ & है: & ని & $\stackrel{8}{\circ}$ & $\begin{array}{l}\text { Weight } \\
\text { of } P r\end{array}$ & กี & $\stackrel{\mathfrak{o}}{a}$ & $\begin{array}{c}\text { weight } \\
\text { of } P i\end{array}$ & 1 & $\begin{array}{c}\text { weight } \\
\text { of Pt }\end{array}$ & & & & \\
\hline $\begin{array}{l}\text { Teacher } \\
1\end{array}$ & & 7.0 & 8.0 & 5.0 & 8.0 & 7.0 & 7.003 & 6.0 & 8.0 & 6.0 & 6.0 & 6.341 & 9.0 & 9.0 & 8.0 & 8.0 & 8.754 & 7.0 & 8.0 & 8.0 & 7.461 & 7.0 & 6.0 & 6.250 & 8.0 & 8.0 & 139 & 43.81 & 7.302 & 2 \\
\hline $\begin{array}{l}\text { Teacher } \\
2\end{array}$ & & 8.0 & 9.0 & 7.0 & 8.0 & 8.0 & 8.056 & 8.0 & 6.0 & 8.0 & 6.0 & 6.760 & 7.0 & 6.0 & 6.0 & 8.0 & 6.659 & 4.0 & 5.0 & 5.0 & 7.461 & 4.0 & 4.0 & 4.000 & 7.0 & 7.0 & 124 & 36.94 & 6.156 & 20 \\
\hline $\begin{array}{l}\text { Teacher } \\
3\end{array}$ & & 9.0 & 9.0 & 9.0 & 7.0 & 9.0 & 8.885 & 5.0 & 8.0 & 5.0 & 5.0 & 5.512 & 8.0 & 7.0 & 6.0 & 7.0 & 7.325 & 7.0 & 8.0 & 8.0 & 7.461 & 5.0 & 6.0 & 5.750 & 8.0 & 8.0 & 136 & 42.93 & 7.156 & 5 \\
\hline $\begin{array}{l}\text { Teacher } \\
4\end{array}$ & & 8.0 & 8.0 & 6.0 & 8.0 & 7.0 & 7.449 & 7.0 & 8.0 & 7.0 & 6.0 & 6.721 & 7.0 & 6.0 & 5.0 & 8.0 & 6.501 & 8.0 & 7.0 & 8.0 & 7.703 & 4.0 & 3.0 & 3.250 & 4.0 & 4.0 & 125 & 35.67 & 5.946 & 21 \\
\hline $\begin{array}{l}\text { Teacher } \\
5\end{array}$ & & 7.0 & 7.0 & 7.0 & 8.0 & 7.0 & 7.057 & 8.0 & 6.0 & 8.0 & 7.0 & 7.029 & 8.0 & 8.0 & 6.0 & 6.0 & 7.508 & 7.0 & 8.0 & 8.0 & 7.461 & 7.0 & 6.0 & 6.250 & 6.0 & 6.0 & 135 & 41.49 & 6.914 & 9 \\
\hline $\begin{array}{l}\text { Teacher } \\
6\end{array}$ & & 5.0 & 5.0 & 5.0 & 8.0 & 5.0 & 5.172 & 7.0 & 8.0 & 7.0 & 8.0 & 7.620 & 8.0 & 8.0 & 9.0 & 7.0 & 8.069 & 8.0 & 8.0 & 8.0 & 8.000 & 8.0 & 8.0 & 8.000 & 5.0 & 5.0 & 135 & 41.86 & 6.977 & 8 \\
\hline $\begin{array}{l}\text { Teacher } \\
7\end{array}$ & & 8.0 & 9.0 & 8.0 & 8.0 & 8.0 & 8.167 & 8.0 & 8.0 & 8.0 & 6.0 & 7.101 & 8.0 & 7.0 & 8.0 & 5.0 & 7.463 & 6.0 & 6.0 & 5.0 & 5.836 & 6.0 & 6.0 & 6.000 & 8.0 & 8.0 & 136 & 42.57 & 7.095 & 7 \\
\hline $\begin{array}{l}\text { Teacher } \\
8\end{array}$ & & 7.0 & 8.0 & 8.0 & 8.0 & 4.0 & 6.496 & 6.0 & 6.0 & 8.0 & 9.0 & 7.589 & 5.0 & 4.0 & 5.0 & 5.0 & 4.728 & 5.0 & 6.0 & 5.0 & 5.297 & 7.0 & 6.0 & 6.250 & 9.0 & 9.0 & 121 & 39.36 & 6.560 & 15 \\
\hline $\begin{array}{l}\text { Teacher } \\
10\end{array}$ & & 7.0 & 8.0 & 7.0 & 8.0 & 4.0 & 6.385 & 7.0 & 6.0 & 9.0 & 9.0 & 7.969 & 7.0 & 6.0 & 5.0 & 5.0 & 6.237 & 7.0 & 6.0 & 8.0 & 6.867 & 3.0 & 4.0 & 3.750 & 8.0 & 8.0 & 124 & 39.21 & 6.535 & 17 \\
\hline
\end{tabular}




\section{ATLANTIS
PRESS}

\begin{tabular}{|c|c|c|c|c|c|c|c|c|c|c|c|c|c|c|c|c|c|c|c|c|c|c|c|c|c|c|c|c|c|c|}
\hline \multirow{3}{*}{ Name } & \multirow{3}{*}{$\begin{array}{c}\text { Criteria } \\
\begin{array}{r}\text { Priority } \\
\text { Vector }\end{array}\end{array}$} & \multicolumn{6}{|c|}{ Pedagogic (Pe) } & \multicolumn{5}{|c|}{ Personality $(K)$} & \multicolumn{5}{|c|}{ Social (S) } & \multicolumn{4}{|c|}{ Professional (Pr) } & \multicolumn{3}{|c|}{ Innovation (Pi) } & \multicolumn{2}{|c|}{$\begin{array}{c}\text { Utility of } \\
\text { Tech }\end{array}$} & \multirow{3}{*}{$\begin{array}{c}\text { Number } \\
\text { of } \\
\text { values }\end{array}$} & \multirow{3}{*}{$\begin{array}{c}\text { Number } \\
\text { of } \\
\text { weights }\end{array}$} & \multirow{3}{*}{$\begin{array}{l}\text { Final } \\
\text { Result }\end{array}$} & \multirow{3}{*}{ Rank } \\
\hline & & Pe1 & $P e 2$ & $P e 3$ & Pe4 & $P e 5$ & \multirow[b]{2}{*}{$\begin{array}{l}\text { weight } \\
\text { of } P E\end{array}$} & $K 1$ & $K 2$ & K3 & K4 & & $S 1$ & $S 2$ & $S 3$ & $S 4$ & & Pr1 & $P r 2$ & $P r 3$ & \multirow[b]{2}{*}{$\begin{array}{c}\text { Weight } \\
\text { of } P r\end{array}$} & Pi1 & $P i 2$ & & $P t$ & & & & & \\
\hline & & ڤે & 5 & 7 & $\stackrel{8}{\circ}$ & $\stackrel{\infty}{3}$ & & $\begin{array}{l}\text { ถิ้ } \\
\text { ลิ }\end{array}$ & $\frac{1}{8}$ & 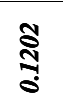 & 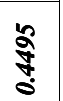 & $\begin{array}{c}\text { weight } \\
\text { of } K\end{array}$ & 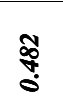 & 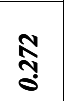 & $\frac{\infty}{5}$ & $\begin{array}{l}\infty \\
\stackrel{0}{0}\end{array}$ & $\begin{array}{c}\text { Weight } \\
\text { of } S\end{array}$ & s. & 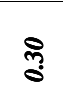 & $\stackrel{0}{0}$ & & $\dddot{2}$ & $\stackrel{\mathfrak{R}}{o}$ & $\begin{array}{c}\text { weight } \\
\text { of } P i\end{array}$ & 1 & $\begin{array}{c}\text { weight } \\
\text { of } P t\end{array}$ & & & & \\
\hline $\begin{array}{l}\text { Teacher } \\
1\end{array}$ & & 7.0 & 8.0 & 5.0 & 8.0 & 7.0 & 7.003 & 6.0 & 8.0 & 6.0 & 6.0 & 6.0 & 9.0 & 9.0 & 8.0 & 8.0 & 8.754 & 7.0 & 8.0 & 8.0 & 7.46104 & 7.0 & 6.0 & 6.3 & 8.0 & 8.0 & 139 & 43.8093 & 7.302 & 2 \\
\hline $\begin{array}{l}\text { Teacher } \\
20\end{array}$ & & 7.0 & 8.0 & 7.0 & 4.0 & 7.0 & 6.995 & 8.0 & 7.0 & 9.0 & 5.0 & 5.0 & 6.0 & 7.0 & 7.0 & 8.0 & 6.606 & 7.0 & 8.0 & 8.0 & 7.46104 & 8.0 & 8.0 & 8.0 & 8.0 & 8.0 & 139 & 43.6628 & 7.277 & 3 \\
\hline
\end{tabular}

